\title{
The influences of A.V. Chayanov and Teodor Shanin on the English-language historiography of peasants in the Russian Empire
}

\author{
C.D. Worobec
}

Christine D. Worobec, Distinguished Research Professor Emerita, Northern Illinois University. 1425 W. Lincoln Hwy., DeKalb, IL 60115-2828. E-mail: worobec@niu.edu.

In the 1980s, various influences were at play in producing a groundswell of interest in the Russian Empire's peasantries, not least of which were the works of A.V. Chayanov and Teodor Shanin. The interdisciplinary social history movement, which eschewed traditional political history and its focus on elites, arose in the 196os. The initial interest in biographies of Russian revolutionary men and women and histories of the nascent Russian working class and labor movement in order to explain the revolutions of 1905 and 1917 were suddenly supplemented and eventually displaced by an avid interest in peasants. The article examines the conclusions that the first-wave of scholarship on the peasantries of the Russian Empire produced. It shows how the ideas of Chayanov and Shanin remained dominant but were challenged by archival sources, histories on the micro- and regional levels, and attention to household tensions, gender issues, craft production and non-agricultural trades, growing literacy, as well as out-migration and return migration. By the mid-1990s, it became impossible to talk about a generalized autarkic, insular, cohesive as well as egalitarian Russian peasant society with traditional mores and customs that rebelled spontaneously because of its immiseration. The post-structural turn had furthermore begun to chip away at the veracity of statistics produced in the late nineteenth and early twentieth centuries and to question depictions of peasants which tended to emphasize their dark, primitive, and seemingly backward nature. Although this turn almost dried up interest in Russian peasant studies, a steady stream of historical works began to appear again in the first decade of the twenty-first century. We now have a firmer grasp of an economically and socially differentiated peasantry, the contours of the normal political accommodation that peasants made with the state (instead of always resisting it), and peasants' utilization of the legal system to challenge their neighbors and family members. Furthermore, we know how a moral economy operated between the state and its peasant taxpayers and how and why zemstvo statistics produced Chayanov's brilliant model of the dominant middling peasant household. At the same time, the agency with which Chayanov and Shanin infused the peasants has taken center stage in historical analyses.

Key words: Chayanov, Shanin, peasantry, Russian empire, Russian peasant society, peasant household, peasant commune, traditional political history, post-structural turn, moral economy

DOI: $10.22394 / 2500-1809-2020-5-4-8-31$ 
In the summer of 1986, two major conferences devoted to peasants in Imperial Russia were held in London and Boston. These meetings followed on the heels of a 1982 colloquium on Russian peasants, which Moshe Lewin and Alfred Rieber organized at the University of Pennsylvania "to get at the Russian peasantry in its own terms", and a 1983 international comparative conference in Montreal, which was devoted to agrarian economies within industrializing Europe, Russia, and North America. Although there was some overlap in the participants, an astonishing total of more than fifty scholars took part in the 1983 and 1986 meetings (Rosenberg, 1993: 843). For the first time, senior and junior scholars shared exciting new research about Russian and Ukrainian peasants in the long nineteenth century, although most addressed the post-emancipation era. Three edited volumes of essays, two of which focused on Imperial Russia, resulted from the discussions (Bartlett, 1990; Kingston-Mann, Mixter, Burds, 1989). Of the latter two, one explored the diverse nature of the Russian commune and the other investigated various aspects of the social, political, and economic life of Russian and Ukrainian peasants. Individual monographs on various topics mainly on the Russian peasantry in the post-reform period appeared either in tandem with the conferences and publications, or soon followed (see, e.g.: Bushnell, 1985; Edelman, 1987; Eklof, 1986; Engel, 1994; Hoch, 1986; Moon, 1992; Ransel, 1988; Seregny, 1989; Worobec, $1986 ; 1991)^{1}$.

Numerous influences were at play in producing a groundswell of interest in the Russian Empire's peasantries, not least of which were the works of A.V. Chayanov and Teodor Shanin. The interdisciplinary social history movement, which rejected the traditional political history and its focus on elites, arose in the 1960s. The initial interest in individual and collective biographies of Russian revolutionary men and women, and histories of the nascent Russian working class and labor movement to explain the 1905 and 1917 revolutions were suddenly supplemented and eventually displaced by an avid interest in peasants (see, e.g.: Bergman, 1983; Evans Clements, 1979; Engel, 1983; Engelstein, 1982; Gleason, 1980; Koenker, 1981; Venturi, 1960; Zelnik, 1971) ${ }^{2}$. The English translation of Chayanov's essays in 1966, Sha-

1. Unfortunately, Zack J. Deal's forward-looking provincial study of the Ukrainian peasants' agricultural practices, which detrimentally affected the environment of the steppe, Serf and State Peasant Agriculture: Kharkov Province, 1842-1861 (1981), came out earlier and got lost in the explosion of the new literature. For a synthesis of the findings of the new historiography see David Moon's magisterial The Russian Peasantry 1600-1930: The World the Peasants Made (1999). See also Ben Eklof's important historiographical essay, "Ways of seeing: Recent Anglo-American studies of the Russian peasant" (1988), which previewed much of this literature. My apologies to scholars whose work I might have inadvertently left out.

2. Robert Eugene Johnson's Peasant and Proletarian: The Working Class of Moscow in the Late Nineteenth Century (1979) constituted an important
C.D. Worobec

The influences of

A.V. Chayanov and Teodor

Shanin on the

English-language historiography of peasants in the Russian Empire 
10 nin's reinterpretation of Chayanov's ideas and those of zemstvo statisticians in his seminal 1972 The Awkward Class, and Jerome Blum's теория 1972 Lord and Peasant in Russia joined Geroid Tanquary Robinson's classic 1932 work on rural Russia in providing common readings on Russian peasants for faculty and graduate students in universities in North America and the United Kingdom (Chayanov, 1966; Shanin, 1972; Blum, 1972; Robinson, 1972). It was no coincidence that Shanin, who was then a faculty member of the University of Manchester, served as a key commentator at the 1986 conferences in London and Boston. At approximately the same time that works on peasants in Russia appeared in English, the French Annales School were producing exciting regional studies of the French peasantry and raising important demographic questions, while the Cambridge School was tackling the reconstruction of households in Europe and elsewhere for comparative purposes (see, e.g.: Goubert, 1986; le Roy Ladurie, 1978; Henry, 1967; Laslett, Wall, 1972) ${ }^{3}$. Last but not least, James Scott's ground-breaking book on the moral peasant economy or subsistence ethic in Southeast Asia appeared in 1976 (Scott, 1976). Including pioneering anthropological works by Eric Wolf (1966) and Robert Redfield (1962), the new field of 'peasant studies' presented the very real possibility that peasant economies across the globe shared similarities, although that assumption still had to be tested (Karagodin, 2002).

The mid-1960s rediscovery of Chayanov's focus on the dynamic peasant household in Imperial Russia and the agency of non-capitalist-minded peasants in determining their expenditure of labor to meet subsistence needs for the reproduction of that economic-social unit provided exciting fodder for social historians. By the early 1980 s, several micro-studies of large serf estates in agricultural areas of pre-reform Imperial Russia had reconstituted peasant household structures, among which complex multi-generational families predominated (Dean Bohac, 1982; Czap, 1978). Those complex family units were supposedly kept in check, at least on large estates, by bailiffs who carried out their absentee serfowners' restrictions on household divisions to maximize labor production on both manorial and communal lands. Even so, smaller and less complex family units did exist, and the dying out and merger of households had to be explored. For the post-reform period, Chayanov's model of the dynamic peasant household provided a stark contrast to the static nature of

transitional work between the Russian working class and peasantry with its emphasis on zemliachestvo, the links that male peasant migrants to the cities kept to their rural communities by seeking out co-villagers or villagers from the same volost in urban areas and returning frequently home to visit wives, children, and parents.

3. Michael Confino's pioneering work on Russia's agrarian systems was inspired by the Annales School. See his Domaines et seigneurs en Russie vers la fin du XVIIIe siècle (1963); and Systèmes agraires et progrès agricole (1969). 
zemstvo statistics. In presenting the average rather than mean sizes of households, populist-minded zemstvo statisticians avoided the subject of household/family structures until the late nineteenth century. By the 1880 s, some zemstvo agronomists joined government observers in their concern over an increasing number of 'weaker' nuclear families resulting from peasants' supposedly 'irrational' behavior in prematurely separating from their households prior to the death of the bolshak or household head ${ }^{4}$. They assumed that these smaller households would remain perpetually nuclear.

Although Chayanov would focus on the life cycle of middling peasant families which tended, as he argued, to be nuclear in composition, he did not discount the existence of complex or extended multi-generational families. These families resulted when a marrying son brought his wife to his father's household to compensate for the marrying daughter who departed the paternal home for that of her in-laws. A nuclear family could similarly become more complex with time before breaking into separate units again. Shanin's expansion of Chayanov's thinking to move beyond the middling peasant (who became prevalent as a result of peasants' seizing private lands in the midst of the 1917 Revolutions) and to view household division as a leveling and equalizing mechanism added to the discussion.

However, Chayanov had not investigated the nature of the hierarchical patriarchal household in which women and children contributed labor shares in subordinate positions to the household head. Nor had he explored the extended and complex family situations in which the bolshukha (the household head's spouse) organized and acculturated the women and children beneath her. Historians of Russian peasants, including myself, Barbara Engel, Beatrice Farnsworth, Cathy Frierson, Rose Glickman, Judith Pallot, and David Ransel, followed Shanin's tantalizing and perceptive lead in pointing to (if not developing) 'sex and age' as important factors within the peasant household that could lead to dissension (Shanin, 1972: 175-177).

At a time when gender had not yet become a major category of analysis in historical work ${ }^{5}$, we began to explore in varying degrees
4. The Administration for Peasant Affairs reported in the 1880 s that 2,371,248 peasant households in forty-six provinces of European Russian had splintered in the two decades since emancipation. Of these, only $12.8 \%$ had been carried out with permission from village assemblies. Provincial governors supplemented the statistics by pointing to a higher rate of household divisions between 1874 and 1884 . The higher percentage of families without an adult male laborer or with only one $-52.4 \%$ for thirty-seven provinees - was thought to reflect the negative effects of household divisions. These numbers proved to be inflated, as demonstrated by the zemstvo statistician N. Chernenkov (Worobec, 1991: 92-94). On other zemstvo statisticians' assessments, see: Frierson, 1987: 37, 39, 43-45.

5. Gender as a category of analysis has become pervasive in scholarship, but it is still a relatively new concept. One of the first volumes on the subject
C.D. Worobec

The influences of

A.V. Chayanov and Teodor Shanin on the English-language historiography of peasants in the Russian Empire 
12 women's agricultural and non-agricultural labor, social, cultural, and monetary contributions to the household as well as their accommodaтеория tion of and challenges to the patriarchy (Worobec, 1991; Engel, 1990; Engel, 1986; Farnsworth, 1986; 1990; Frierson, 1987; Glickman, 1991; Pallot, 1991; Ransel, 1988). Women's championing of their customary property rights in the volost (township) courts, for example, revealed tensions within the peasant household that did not conform with the notions of an egalitarian peasant society that minimized dissension through the leveling mechanisms of the strong "traditional social structure..., family loyalties, ...[and] pressure from [the] conservative public opinion of the village community" (Shanin, 1972: 175). Well before the World War I, scores of daughters-in-law, soldiers' wives, childless widows, and later wives of migrant husbands fought their marginalization within larger households and sometimes disinheritance. Some even sought separations from abusive husbands. I only mention the war years here, because Shanin saw them as providing the pivotal moment when women took charge of the domestic agricultural economy and participated more fully in village self-government, allowing them to act from a position of strength (Shanin, 1972: 275276). Women's protests against the Stolypin reforms and price gouging during the war were instrumental in adding a domestic side to the increasing battlefront fatigue, desertions, and anger with the state manifested by rank-and-file peasant soldiers, these women's husbands, fathers, and other kin (see, e.g.: Engel, 1997; Badcock, 2004; Baker, 1999; Moore, 2018) ${ }^{6}$. It is nonetheless equally important to understand that changes in peasant women's roles and status had begun earlier. Women in areas of heavy male out-migration in the Central Industrial Region and the north had increasingly enjoyed enhanced economic and political positions from the $1880 \mathrm{~s}$ onwards, establishing what Dmitry Nikolaevich Zhbankov identified as 'women's kingdoms' (Zhbankov, 1891; see also: Engel, 1986; 1994). Independent-minded women in various regions were also instrumental in pleading for pre-mortem household divisions throughout the post-emancipation era (Frierson, 1987: 46-47, 49; Worobec, 1991: 80-82).

Unfortunately, physical violence against women within the peasant household may have impeded a majority of women from rebelling against their subordination. At least Orthodox peasant women could escape that violence temporarily by leaving the village periodically as pilgrims to holy shrines at monastic institutions near and far to commune with other women and to seek the help of their saintly in-

appeared in the collection of anthropological essays (Ortner, Whitehead, 1981). Joan Wallach Scott's seminal essay (1986) revolutionized many social historians' thinking about women's history but it took them many years to produce scholarship centered around the concept of gender.

6. I am grateful to Dr. Moore for providing me with a copy of her book chapter. 
tercessors ${ }^{7}$. Others in the Central Industrial and northern regions enjoyed reprieve from spousal abuse when their migrant-laboring husbands were absent from the village for lengthy periods, although in complex households they remained vulnerable to abuse from in-laws who cast aspersions on their family loyalty, work habits, and marital fidelity (Engel, 1986).

Shanin's general argument that "centripetal' (leveling) mechanisms of peasant household mobility outweighed 'centrifugal' (differentiating) mechanisms" (Bernstein, 2018: 1132), pushed the historians of the 1980 s and 1990s to test the theory and some of Shanin's other claims in The Awkward Class. Archival sources, micro- and regional case studies of peasants, growing attention to artisanal production and other non-agricultural trades (such as wet-nursing, thread and cloth-making, and fashioning the paper mouth pieces for papirosy [cigarettes]), increasing literacy, male out-migration and return migration highlighted differentiating factors and the heterogeneity of Russian and Ukrainian peasants. Local social-economic conditions, local and regional identities and customs, as well as varying land tenure and communal systems had to be taken seriously (Worobec, 2003: 256-276). These conclusions would not have surprised Shanin who came to realize that "peasant studies [entailed] a journey of discovery" and that peasant societies were in constant flux (van der Ploeg, 2018: 694). By the mid-199os, it was becoming increasingly impossible for specialists to talk about a generalized autarkic, insular, cohesive as well as egalitarian Russian peasant society with traditional mores and customs, which rebelled spontaneously because of its steady immiseration amidst the exploitation of the state, although these characterizations remained entrenched in textbooks.

Contrary to the prevailing view that went back to Robinson's work and one to which Shanin subscribed in Russia as a 'Developing Society' (1986), the Russian peasants' standard of living had by the early twentieth century in fact improved. Economic historians Paul Gregory, Stephen Wheatcroft, and Peter Gatrell looked at grain harvest yields, sown land, and taxes, asserting that only in the vast steppes of the Volga, where the 1891 famine hit the hardest, was low-yield agriculture the norm (Gregory, 1983; 1994; Wheatcroft, 1991; Gatrell, 1986). "Richer peasants in the Central Non-Black-Earth Region around Moscow and, especially, the peripheral regions of the NorthWest, Baltic, Southern Ukraine, and Siberia diversified into commercial production of grain, [and more profitable] industrial crops such as flax, livestock and dairy produce" (Moon, 2005: 122). More recently, economic historians point to 'the competitive if not superior' nature

7. Brenda Meehan first drew attention to the importance of pilgrimages in the lives of Orthodox women of various classes in her Holy Women of Russia: The Lives of Five Orthodox Women Offer Spiritual Guidance for Today (1993: 52, 63-69, 75, 77, 127).
C.D. Worobec

The influences of

A.V. Chayanov and Teodor

Shanin on the English-language historiography of peasants in the Russian Empire 
14 of communal family farms in producing labor-intensive crops vis-àvis 'private farming' even in the Central Industrial Region. They conтеория clude that open-field communal farming with its rising overall yields "might have minimized... enormous risks" in adapting to market conditions (Kopsidis, Bruisch, Bromley, 2015: 438, 441; Leonard, 2011: 137140). At the same time, peasants in some communities introduced a four-field system and/or planted fodder crops, demonstrating once again the flexibility rather than the rigidity of communal agriculture (Kingston-Mann, 1991). Still other peasant communities had ceased repartitioning allotment lands to avoid losing precious allotment lands when the number of laborers or eaters in the households decreased as part of the normal family life cycle. Rented and purchased land also increased the peasants' arable land as demographic pressures set in.

Male out-migration in the Central Industrial Region to Moscow and Saint Petersburg affected village economies far more positively than historians initially assumed as households became dependent upon the remittances of wage labor and were inundated with coveted consumer goods (Burds, 1998: Ch. 6). Comfortable and sanitary cotton dresses, aprons, and headscarves had become common in the late nineteenth century countryside. More fashionable clothing also reflected women's growing self-worth and independence. Male migrants, who tended to retire in the village, brought independent ideas and ways, although ultimately they did not abandon patriarchal thinking when became household heads.

As historians' findings began to challenge the picture of peasant backwardness irrationality painted by the late nineteenth-century commentators, the post-structuralist turn in historical studies forced scholars to question the veracity of supposedly objective and scientific Russian government statistics on peasants, including those compiled by populist-minded zemstvo statisticians, and to uncover the purposes behind their collection". Paradoxically, in hoping to "discover in their mounds of socio-economic data a communal 'law of gravity' that demonstrated that communal institutions need not be abandoned in order to ensure Russia's economic future", zemstvo statisticians with their socially constructed data, according to David Darrow, unwittingly "offered defenders and detractors of the commune a [critical] tool with which to examine communal life" (Darrow, 2001: 789; see also: Stanziani, 2017). Ultimately, government reformers used zemstvo data to dismantle the 'backward' commune immediately after the 1905-1907 Revolution by the utopian Stolypin reform project. This was a time when the state no longer found the commune palatable and a bulwark against peasant unrest. Although peasants were able

8. For a pioneering work on the problems with Russian government statistics regarding crimes committed by women, see Stephen P. Frank's "Narratives within numbers: Women, crime and justicial statistics in Imperial Russia, 1834-1913 (1996). 
to mold the Stolypin project to suit their needs, as brilliantly demonstrated by Judith Pallot, the reforms also allowed them, according to Corrine Gaudin, to attack the subsistence rights of widowed household heads and other marginal women and enhance patriarchal power (Pallot, 1999; Gaudian, 1998).

In addition to quantitative data, qualitative materials produced in the post-emancipation period became suspect in the eyes of historians. These accounts were all penned by observers of peasants who had their own agendas. According to Stephen Frank, 'moral reformers' from among the middle- and upper-classes sought to displace supposedly disruptive and uncivilized forms of popular entertainment with more "rational' recreations and invented traditions". These demonizers emphasized the peasant culture's hooligan nature, its degeneracy, lawlessness, and decay by portraying rising numbers of rural crimes, alcoholism, and out-of-control carousing at holiday celebrations, markets and fairs. By doing so, they obscured peasant practices (Frank, Steinberg, 1994: 8, 75; see also: Frank, 1992). In fact, distinct peasant voices and distinctive facets of their individualism remained opaque. Even more damning were the stereotypes of the backward, grey peasant masses and female peasant viragos and shrews (who at other times could paradoxically be victims), and the exploitative village $k u$ laks that observers, intellectuals, and the literati perpetuated in the late nineteenth century as the populist idealism of peasants had taken a toll after the movement to the people of the mid-1870s to foment revolution had fizzled out due to peasants' lack of enthusiasm. Cathy Frierson's systematic deconstruction of writers' prejudices and assumptions about Russian peasants made the veracity of these writers' descriptions of peasant everyday life suspect (Frierson, 1993).

Similarly, the discourses and policies of late imperial economists, agronomists, and senior government officials to modernize Russia's peasants with "ostensibly benevolent rationales" came under historians' scrutiny (Kingston-Mann, 1999; Kotsonis, 1999) ${ }^{9}$. One of them focuses squarely on the language used by zemstvo agronomists, including Chayanov, in promoting agricultural cooperatives. In a highly analytical work Yanni Kotsonis dismisses the claims by agronomists' and other champions of the cooperative movement to integrate peasants into society and promote their creativity and independence as mere rhetoric. He argues instead that the educated elites patronized and infantilized peasants, while viewing their own roles as specialists, civilizers, and supervisors, as being integral to the cooperatives' success. "The issue to them was how to use knowledge and material improvement to transform a population [the peasantry] that they believed could not conceive of transforming itself" (Kotsonis, 1999: 95). Without the specialists' guiding hands, helpless and back-

9. The quotation is from Andy Bruno's "Russian environmental history: Directions and potentials" (2007: 641). 
ward peasants would simply allow their economic enterprises to fall into the hands of village exploiters (the so-called 'kulaks'). Kotsonis теория quotes Chayanov's 1918 revised handbook for agronomists as noting that "those broad masses who populated the Russian plains... had neither a voice, nor a creative will, nor a conscious public thought, because they were and they remained atomized". Reacting negatively to peasants attacking the technocrats on the ground in the revolutionary years 1917-1918, Chayanov further lamented that "the Russian people was a demos, a dark human mass, whilst it should have been a democracy - a people conscious of itself. And it lacked organization, public experience, and organized public thought to transform from a demos to a democracy" (Kotsonis, 1999: 187). Kotsonis forcefully comes to the conclusion that while the Stalinist "dekulakization and military assaults on entire 'kulak regions' was hardly what cooperators had in mind... They had shared in and contributed to the premise that an attack on kulaks was, in effect, an attack on the villages that produced the kulaks, fed their power with ignorance and inertia, and lacked the consciousness to oppose or even recognize their enemies". Dekulakization was not simply "an assault on capitalists, traders, [and] kulaks". It was "above all [an assault on] backwardness" or what might be better expressed as an attack on a perceived backwardness (Kotsonis, 1999: 188) ${ }^{10}$.

Although scholars might not agree with all the conclusions of the early post-structural works on the late nineteenth- and early twentieth-century discourses about the Russian peasantry, concrete evidence was mounting that the notion of peasant backwardness constituted an entrenched construction of Russian educated classes and that contrary to that pessimistic evaluation peasants had been successfully adapting to population pressures, market forces, and the economic opportunities afforded by urbanization and modernization. The abandonment of the paradigm of backwardness in the Anglo-American historiography helps to explain partly why Shanin's Russia as a 'Developing Society' received less attention than it might have otherwise and did not influence future writings in the same way that The Awkward Class did. Shanin's overall conclusion that "the accumulated contradictions of backwardness within developing society led Russia to the inevitable, revolutionary consequences of the beginning of the twentieth century" struck historians as problematic not only because of its emphasis on backwardness (Nikulin, Trotsuk, 2020: 1552).

Some historians were beginning to move beyond reading the Russian history backwards and assuming that the Revolution of 1905 and the subsequent revolutions of 1917 were inevitable. There was also a clash of disciplines in play as historians do not subscribe to mod-

10. For a critical assessment of Kotsonis's work see Ilya V. Gerasimov's "On the limitations of a discursive analysis of 'experts and peasants' (An attempt at the internationalization of a discussion in Kritika)" (2004). 
els. Neither do they search for a universal peasant type. Shanin's argument "that pre-revolutionary Russia was a developing society and that its revolutions were the first of a kind" as well as implication that "revolutions of the 'Russian type' continue to be historically possible" in developing societies fell on Russian historians' deaf ears (Djurfeldt, 1988). That said, the preeminent historian of Russia and Eurasia Alfred Rieber applauded Shanin's second volume of Roots of Otherness noting that it constituted "one of the best treatments of the Revolution of 1905-1907 in any language" (Rieber, 1988; Shanin, 1986). Shortly thereafter, Robert Johnson (the specialist on peasant out-migration to Moscow) wrote that some of that volume's "most impressive pages are devoted to the 'Peasant Dream', a synthesis of old and new, which Shanin defined as a "terminology of conservatism, conventionality, patriarchalism, religion and often parochialism and semi-magical beliefs injected with new and radical words, views and experiences, and put to use to grasp and shape a rapidly transforming society" (Johnson, 1991: 1248). Based on prodigious research, Shanin's second volume remains the definitive study of peasant rebellions in the first Russian Revolution ${ }^{11}$.

Although the post-structural turn might have and, indeed, seemed to many scholars to have sapped interest in Russian peasant studies by challenging the veracity of historical statistics gathered on ideological grounds and contemporary observers' descriptions of peasants' activities and world view (Gerasimov, 2004: 261), a steady stream of historical works began to appear again in the late 19gos and first decade of the twenty-first century. These publications resulted in part from the early 1990s' opening of the Russian and Ukrainian national and regional archives, especially fonds dealing with religious and legal matters that provide better documentation about peasants' behavior and beliefs. The gap can also be explained by the fact that those historians of the first wave of English-language publications on peasants in Imperial Russia, who decided to return to this subject matter, generally took about a decade to produce new works. In some cases, an abundance of archival materials and the necessity of more frequent research trips abroad to access those materials slowed down the completion of projects. A third factor also came into play, which may have had the adverse effect of newly published works sometimes falling under the radar of specialists on the peasantry. As historians of imperial Russia grabbled with the post-structural critique and the need to historicize all primary sources, they were forced to provide information about and analyses of not only peasants but also the individuals who wrote about and interacted with them. In doing so, they often turned to unexplored subjects that sometimes come under the

11. Only a couple of scholars in the United States have written monographs on peasant rebellions in 1905-1907 and they are both excellent. See; Seregny, 2013 .
17

C.D. Worobec

The influences of

A.V. Chayanov and Teodor

Shanin on the

English-language historiography of peasants in the Russian Empire 
18 rubric of historical subfields other than peasant studies. These include the new cultural history, religious history, legal history, environmenтеория tal history, and the history of empire and colonization, most of which have become more fashionable in the historical profession in the last few decades. Some of the titles of works discussed below do not include 'peasants' or other key words such as 'countryside' or 'rural' in their titles. The compartmentalization of historical studies in recent years can sometimes be its own worst enemy as it becomes more difficult for scholars to cross various divides or read beyond their own narrower interests. On the other hand, these new approaches have broadened our understanding of peasants.

Chayanov's and Shanin's emphasis on social-economic factors as being dominant in shaping the lives of Russian peasants and their Ukrainian counterparts mirrored the thinking of their contemporaries - be they the economists and agronomists of the late Imperial period or the post-World War II anthropologists, sociologists, economists, and historians who studied peasants around the globe. What was conspicuously absent from the discussions of peasant societies was an attempt to uncover their actual religious world views. References to peasants' traditions and superstitions certainly abounded and fit Shanin's concept of centripetal forces within the peasant community, but they were always in the context of peasants' traditionalism and primitivism or lack of civility, traits that would disappear with modernization, whether it be capitalist or non-capitalist in nature. Secularization theory dominated all disciplines until relatively recently. Steadfast belief in the hegemony of secular norms and dechristianization was only entrenched by what appeared to be the success of the atheistic Soviet regime. It did not help historians of the Russian and Ukrainian peasantries in their attempts to discover pure or authentic peasant beliefs that dated back to pre-Christian or pagan times, because the nineteenth-century ethnographers who chronicled peasants' religious beliefs generally focused on those beliefs they labeled as being divorced from established religion. Their embrace and propagation of the concept of dvoeverie, which they erroneously defined as consisting ancient beliefs covered with a thin veneer of Orthodoxy or at best an amalgam of paganism and Orthodoxy, to describe peasant beliefs in the modern era has had tremendous holding power on scholarship to this day (Levin, 1993; Worobec, 1994; Rock, 2007). The successful revival of the Orthodox Church and other religious dominations in both Russia and Ukraine has nevertheless severely punctured the secularization and dechristianization paradigm.

As a social historian of post-emancipation Russian and Ukrainian peasants, I had little inkling that I would delve deeply into a study of Russian Orthodoxy when, in the early 199os, I embarked on what became a study of demonic possession in Imperial Russia (Worobec, 1992). I use my own experience to demonstrate how my subject matter evolved as I unexpectedly made the transition from a social historian 
to a cultural historian once new primary sources came to my attention and I found myself needing to take post-structuralism seriously. My original research plan, influenced by Moshe Lewin's stimulating essay on Russian peasants' religious beliefs and their fascination with demons on the eve of collectivization, involved conducting a comparative study of demonology among Russian, Ukrainian, and Belarussian peasants (Lewin, 1985). The project soon evolved into a comparative study of witcheraft among Russian and Ukrainian peasants (for which ethnographic and legal descriptions existed) (Worobec, 1995; see also: Frank, 1987; 1999).

As soon as I discovered religious writings, particularly the genre of miracle tales, as well as early twentieth century psychiatric reports about what doctors deemed to be epidemics of religious hysteria in the countryside, I found myself having to grapple with the phenomenon of klikushestvo or demonic possession. That meant uncovering its definitions, its provenance and evolution, and, in following the lead of Stephen Frank and Cathy Frierson, its representations. The feminization of possession starting in the early eighteenth century with Peter I's decrees, and its increasing peasantization beginning in the mid-nineteenth century with the medicalization of hysteria in the treatment of upper- and middle-class women meant that by 1861 demonic possession had become almost exclusively a rural phenomenon. It could periodically disrupt urban centers after the 1860 s - with the growth in numbers of peasant women pilgrims - and by the end of the century of peasant women migrants. Klikushestvo joined other aspects of peasant life, which in the eyes of educated society symbolized backwardness, deviance, disorder, suffering, irrationality, and ignorance. Like the fin-de-siècle professional agronomists who wished to civilize and modernize peasants, psychiatrists sought to tame peasant women's unbridled passions, atavism, and backwardness with masculine scientific rationalism. Convinced that demonic possession was a pathological rather than a spiritual illness, doctors tried unsuccessfully to wrest control of the diagnosis and treatment of klikushestvo from Orthodox monks, priests, and popular spiritual healers. In the script of the possession drama, clerics and believers shared a similar language, which meant that clerics took seriously their flocks' fears and angst. As it turns out, the thaumaturgical ministrations of Orthodoxy clergy were far more humane than the incarceration and bromides the psychiatrists offered.

Other contemporaneous studies of peasants' religiosity concentrated their attentions more squarely on peasants' beliefs, often within the framework of modernization theory. In his study of "the role of religion among Orthodox peasants in Voronezh province" Chris Chulos demonstrates the ways in which peasants integrated ritual and theology into their daily practices (Chulos, 2003: 4). As an astute reviewer commented, he convincingly demonstrates that "their religion was no less real than that of intellectuals and church authorities schooled in

C.D. Worobec

The influences of

A.V. Chayanov and Teodor Shanin on the English-language historiography of peasants in the Russian Empire 
20 religious thought" (Burbank, 2004: 651). Overturning the stereotypes of peasants as traditionalists and fatalists, Chulos argues that popuтеория lar religious practices in the home and community as well as peasants' marking of religious feasts, their making of pilgrimages to local and national saints, and their engagement with a growing Orthodox religious literature as they became more literate provided peasants with a sense of security and hope for future within a modernizing society ${ }^{12}$. These practices were also critical to villagers' understanding of their history and identity at both the local and national levels.

Sergei Zhuk is another proponent of modernization, but he does so in an entirely different way than Chulos (Zhuk, 2004). In examining a number of radical sects that emerged among Ukrainian and Russian peasants in the southern provinces between 1830 and 1917, Zhuk argues that peasants ultimately combined sectarian mysticism and religious enthusiasm with the Lutheranism and Anabaptism they learned from their German-speaking Lutheran and Mennonite neighbors and former colonizers, and Baptist ideas. In doing so, they became bearers of what Zhuk describes as a Weberian enlightened modern Protestant ethic. As productive, sober, non-violent, disciplined, individualistic, and promoters of women's religious authority (although some of women were sexually abused by religious leaders), they appear in Zhuk's analysis as being morally and spiritually superior to their Orthodox counterparts, from which they had stemmed, and disdainful of what he describes as a staid and incompetent Orthodox church. This picture contrasts starkly not only with Chulos work, but also with other studies that demonstrate a growing vibrant religious culture within the Orthodox world of the empire, which fostered sectarian groups as well as a better informed Orthodox laity, growing monasticism, especially among women, and social services to the laity, among other developments (see, e.g.: Engelstein, 1999; Kivelson, Greene, 2003; Kizenko, 2000; Paert, 2010; Shevzov, 2004) ${ }^{13}$.

In turning to criminal and legal studies, we also see a mixture of post-structural approaches with more conventional social historical approaches. While I was working on my study of klikushestvo, Cathy Frierson undertook the huge task of researching and writing a cultural history of arson in late Imperial Russia from all angles (Frierson, 2002). In All Russia is Burning! she traces the ubiquitous presence and threat of fire in the countryside in the second half of the nineteenth century, peasants' intimate knowledge of fire and its uses, and the very real presence of arson, which peasants used against each other for purposes of revenge, social leveling (one of Shanin's centripetal elements), and

12. For a different approach that hews more closely to the stereotype regarding the fatalism and traditionalism of Russian peasants, but is more sensitive to the Orthodox context of these beliefs see: Heretz, 2008.

13. For a superb recent synthetic work describing Orthodoxy's vibrancy over the course of the long nineteenth century see: Poole, 2018. 
censure. Armed with her intimate knowledge of post-structuralism, she also traces the apocalyptic rhetoric that some members of the educated society used to describe peasant practices, charging peasants with sloth and ignorance when fire erupted. Even male peasants sometimes unjustly charged their womenfolk with "negligent and willful pyromania" (Brower, 2004). Positivists, on the other hand, perceived the "fire question' to be a pathology that needed taming and controlling. At the same time, in contrast to the works of Darrow and Kotsonis, Frierson paints a positive picture of zemstvo reforms and reformers. In the 18 gos, changes in zemstvo fire insurance programs, the introduction of building codes and new roofing types, and the establishment of voluntary intraclass firefighting brigades were intended to mitigate the effects of fire and reduce its occurrence. She persuasively argues that fire holds the key to explaining Russia's relative economic poverty in the modern era (wiping out almost 2.7 billion rubles worth of property and crippling communities for months and even years between 1860 and 1904) and illuminates how by the early twentieth century peasants joined forces with zemstvo specialists to battle a scourge that repeatedly taxed the countryside's resources.

The accommodation that peasants made with government officials at the local level is broadened in Corinne Gaudin's study of Russian peasant communities after the state's imposition of the land captain in 1889 in the countryside to supervise the peasant local self-government (which amounted to an unprecedented intrusion of the state in peasants' affairs), to describe the normal and ongoing political accommodations that peasants made with the state in everyday life (Gaudin, 2007). Contrary to Shanin's and Scott's thinking, peasants were not constantly resistant to outside forces or in confrontation with a reforming state. Having worked through archival records from the central provinces of Moscow, Riazan, Tambov, and Tver, Gaudin systematically examines how peasants utilized the legal system at the volost level and the newly introduced appeal level to challenge and settle scores with their neighbors and family members. According to Gaudin, "more often than not peasants sought to appropriate the weapons of the strong against village rivals" and sought the support of state officials in their disputes. She debunks the stereotype of peasants being at the mercy of kulaks and miroedy. The peasants' new and ongoing close interaction with the state even during the Stolypin reforms, when tensions among communal members over land and rights increased, as Gaudin argues, raised peasants' expectations for a just and non-arbitrary state that remained too slow to respond to their needs. When the Romanov dynasty and its state structure collapsed in 1917 , peasants turned to their own ways of doing things to deal with their ongoing rivalries. This turn to the local was anything but a triumph of peasant communalism (Gaudin, 2007: ix).

Gaudin's arguments also stand in contrast to those of Jane Burbank, who in her meticulous study of volost court records from ten 
townships, mainly in the vicinity of Moscow and Saint Petersburg (but limited to 1905 through 1917), argues instead that those records теория illuminate an upwardly mobile and more urbanized peasantry who turned to the volost courts in increasing numbers to resolve disputes between neighbors and family members in a peaceful and orderly fashion. Based on this evidence, Burbank concludes that these peasants were integrating themselves into modern institutions and a lawbased society, and as such were becoming a part of the civil society. Although she cautions that her townships cannot be considered representative, she criticizes peasant studies as being too insular and goes so far as to claim that the field's usefulness is passé (Burbank, 2004). Clearly, the documents concerning peasant appeals of volost court decisions and land captains' assessments of villagers' disputes reveal a more complex set of circumstances in other areas of Moscow and other provinces in Russia's center. If Burbank's arguments hold with corroborating evidence from the appeal cases arising from some of the legal suits she studied, we may come away with a greater differentiated and complex peasantry.

The upward mobility of peasants, to which Burbank points, was in fact initially studied by Ben Eklof in his 1986 Russian Peasant Schools with regard to the biographies of zemstvo schoolteachers, who often came from peasant backgrounds. More recently, Ilya Gerasimov, in trying to break the log jam that he feels the post-structural turn introduced in Russian peasant studies, has studied upwardly mobile peasants after 1907, who graduated from the Moscow Agricultural Institute (where Chayanov studied) and more democratic agricultural colleges to become professional cadres in the countryside. He also examines the post-1905-1907 "voluntary correspondents of the zemstvo statistical bureaus", who wrote for a peasant audience, noting that the majority of these writers were peasants (Gerasimov, 2004; 2009). That cooperation between zemstvo professionals and villagers also reminds us of the teamwork that Frierson discovered in fighting fire in the Russian countryside in the early twentieth century.

Another positive link between professionals and peasants may be found in the pioneering and exciting work by David Moon on agriculture and the environment in the Russian and Ukrainian steppes between 1700 and the World War I, which is being lauded by environmental historians and historians of the Russian and Ukrainian peasantries alike (Moon, 2013). In this book, nature and agricultural science loom large as major protagonists. Nature challenged the multi-ethnic settlers who began arriving in the steppe region in the eighteenth century and continued to do so well past 1917. In response, agricultural science helped settlers to devise a more sustainable agriculture after the tried-and-true ways of farming sapped the black earth of its richness. Moon joins Ransel as one of the few historians of the peasantry in the pre-revolutionary period (who tend to work 
exclusively with archival and library materials) to have done field research, which was made possible only because of the fall of the Soviet Union and eventual relaxation of travel for foreigners (Ransel, 2000)14. Moon "visited the remaining grassland reserves in southern Russia and Ukraine and felt firsthand the long-term implications of the [monumental] changes" his documents revealed (Sunderland, 2014). The colonials' encounter with a totally new environment eventually led to new ways of farming after their traditional methods led to the steppe's deforestation. Combined with changes in climate producing more arid and windier conditions, the soil began to erode, became desiccated and exhausted. The extensive nature of peasant agriculture, which meant farming virgin areas after the older fields were no longer fertile (a practice successfully devised for a very different environment), added to the problems. As Mennonite farmers and agronomists (including the soil scientist Vasily Dokuchaev and others) experimented with new techniques - lighter plows, tree-planting, irrigation, crop rotations, longer fallow periods, and leaving swathes of steppe grasses in place to hold down the soil - peasants' initial reluctance to adopt them, according to Moon, "was less a symptom of backwardness or local resistance than slow adaptation to a changed environment" (Bruno, 2014: 697) ${ }^{15}$. Adaptations began to occur in the late nineteenth and early twentieth centuries.

In another new exciting work, which is less about peasants than the Russian government, David Darrow shows a different side of the relationship between the state and its peasants by demonstrating the ways in which a moral economy operated between the two (Darrow, 2018). According to that economy's logic, the autocratic state believed that it had a moral responsibility to fulfill the subsistence needs of peasants by provisioning them with land allotments as part of the emancipation agreement. However, as those allotments proved to be increasingly inadequate as dramatic population growth ensued, the state "consistently failed to create 'normal' peasants - ... [in other words] those who could subsist on their allotted land alone, using only their household's labor" (Moore, 2019). In uncovering the details of this obsession with the nadel, which led to peasants' growing dissatisfaction with the state in not providing them with enough allotment land, Darrow explains how and why zemstvo statistics helped Chayanov produce his

14. David L. Ransel and his collaborators conducted oral interviews in the early 1990 s of three generations of village women, the first cohort of which was born before approximately 1912. For comparative purposes they interviewed not only Russian women, but also Muslim Tatar women about their birthing and childrearing practices and beliefs.

15. Leonard G. Friesen, who grew up on a Mennonite farm in Ontario and has extensive farming experience, has also written about Mennonites' farming innovations in New Russia and their positive influences on neighboring Russian and Ukrainian peasants. See: Friesen, 1994; 2008.

\section{3}

C.D. Worobec

The influences of

A.V. Chayanov

and Teodor

Shanin on the

English-language

historiography of peasants in the

Russian Empire 
24 brilliant model of the dominant middling peasant household within a specific social and political context (Bruisch, 2010) ${ }^{16}$.

теория At the same time, the agency with which Chayanov and Shanin infused the peasants of Imperial Russia in terms of their controlling family size has taken center stage in John Bushnell's 2017 pathbreaking book on Spasovite Old Believer serf women over the course of a century and a half, beginning in the early eighteenth century. As it turns out, the best and most accurate documentary sources (especially demographic information) we have on peasants in the Russian Empire come from the data that bailiffs and serf-owners collected on their estates before emancipation. Having conducted decades of careful and onerous demographic work with these archival materials, Bushnell demonstrates the ways in which Russian peasants controlled and negotiated their economic and social destinies within the confines of serfdom. He uncovers a growing incidence of marriage refusal among women within villages of Russia's upper Volga region. Their rejection of marriage was based upon the Spasovite confession's "existential despair at living in a world in which God had no interest" (Bushnell, 2017: 289). In order for this resistance to marriage to succeed, these women required the support of fathers, brothers, and bailiffs because their maintenance of celibacy upset the abilities of peasant households to reproduce demographically and to sustain economic viability through the practice of almost universal marriage. Here religious beliefs served as a centrifugal force in village communities.

Disrupting peasants' exchanges of daughters among households through marriage alarmed serf-owners and Orthodox peasants alike. Serf-owners from the mid-eighteenth-century onward reacted by charging higher departure fees for brides who married off their estate and by fining households containing unmarried mature women and men. They ended up profiting from increasing the latter fines once they discovered that they could not halt the practice of marriage aversion. Even Spasovite men soon realized that if their households were to survive, given the increasing numbers of dependent women they had to support, they had, like their Orthodox neighbors were now forced to do, to travel to more and more distant estates in search of non-Spasovite brides. Alternatively, they married Spasovite women who rejected the new emphasis on celibacy. Ultimately, Spasovite men's accommodation to economic reality, while at the same time supporting their righteous female relatives' and non-relatives' choice not to marry, did not prevent the economic and demographic weakening of households and sometimes their extinction. Indeed, economic hardship, according to Bushnell, seems to have ended the practice of marriage aversion among Spasovite women in the mid-nineteenth century. Women's agency and resolve had nonetheless been key fac-

16. A similar historicizing of Chayanov's thinking is presented by Katja Bruisch. I am grateful to Dr. Bruisch in sharing a copy of her important essay with me. 
tors in disrupting traditional Russian marital practices that peasants had devised for their households' and communities' survival in a system that rewarded households with "village resources based on the number of its married couples" (Bushnell, 2017: 116). Chayanov's sensitivity to the importance of household composition, Shanin's early writings on the workings of the peasant economy, and expansion of Chayanov's understanding of household reproduction have indeed "withstood the test of time" in Bushnell's remarkable work (1988: 87).

In conclusion, this foray into the evolving English-language historiography on peasants in Imperial Russia since the 1980 s shows that the influences of Chayanov's and Shanin's thinking were strongest in the first phase of that historiography, which lasted a couple of decades. This was a period when interest in the peasant family, household structures, peasant economy, and functioning of the commune was at its highest. In tandem with this interest, scholars began to turn more and more to women's roles in a patriarchal culture within both household and community. At the same time, although scholars had always been critical in evaluating their sources, those sources themselves by the mid-19gos became the subject of historical inquiry. Historians were beginning to pay more attention to intellectual and cultural history. Several scholars began to dissect the writings that had been produced by contemporary observers and commentators to reveal their ideologies which shaped what they wrote and thought about peasants. This post-structural criticism also applied to the scientific gathering of statistics after emancipation and the overall conclusions of those statistics. That criticism was not done in isolation but was part and parcel of a larger questioning of statistics in general by historians studying modernizing bureaucracies around the world.

The discovery that the backwardness and traditionalism of Russian and Ukrainian peasants, which dominated the thinking of the late Imperial Russian elites, was in essence a construct rather than a mirror of reality had a dramatic impact upon the study of peasants. The opening of the archives in Russia and the newly independent Ukraine after 1991 as well as newer historical approaches also fostered new inquiries. The English-language works of the early twenty-first century on the peasantries in Imperial Russia nevertheless do engage with the ideas of Chayanov and particularly Shanin as well as the government reformers and specialists of late Imperial Russia. They are still evaluating the centripetal and centrifugal forces within peasant societies that Shanin identified and in doing so are revealing more complex and evolving peasant societies and forces that allowed upward mobility among peasants. More case studies, sustained comparative work to include non-Russian and non-Ukrainian agriculturalists, and the continuing engagement with religious studies, environmental history, legal history, colonial history, and other approaches will reveal further understandings of not only peasants but also society as a whole in Imperial Russia. 
ТЕОРИЯ Badcock S. (2004) Women, protest, and revolution: Soldiers' wives in Russia during 1917. International Review of Social History, vol. 49, no 1.

Baker M. (1999) Rampaging soldatki, covering police, bazaar riots and moral economy: The social impact of the Great War in Kharkiv Province. Canadian-American Slavic Studies, vol. 35, no 2/3.

Bartlett R. (Ed.) (1990) Land Commune and Peasant Community in Russia: Communal Forms in Imperial and Early Soviet Society, London: Macmillan in association with the SSEES, University of London.

Bergman J. (1983) Vera Zazulich: A Biography, Stanford: Stanford University Press.

Bernstein H. (2018) The 'peasant problem' in the Russian Revolution(s), 1905-1929. Journal of Peasant Studies, vol. 45, no 5-6.

Bernstein H., Friedmann H., Shanin T., van der Ploeg J.D., White B. (2018) Forum: Fifty years of debate on peasantries, 1966-2016. Journal of Peasant Studies, vol. 45, no 5.

Blum J. (1972) Lord and Peasant in Russia: From the Ninth to the Nineteenth Century, Princeton: Princeton University Press.

Bohac R.D. (1982) Family, Property, and Socioeconomic Mobility: Russian Peasants on Manuilovskoe Estate, 1810-1861. PhD dissertation, University of Illinois at Urbana-Champaign.

Brower D. (2004) Review of Frierson's All Russia is Burning! Slavic Review, vol. 63, no 1.

Bruisch K. (2010) Historicizing Chaianov: Intellectual and scientific roots of the theory of peasant economy. Jahrbuch für Geschichte des ländlichen Raumes, vol. 7, pp. 96-113.

Bruno A. (2007) Russian environmental history: Directions and potentials. Kritika: Explorations in Russian and Eurasian History, vol. 8, no 3.

Bruno A. (2014). Review of Moon's The Plough That Broke the Steppes. History, vol. 99.

Burbank J. (2004) Review of Chulos's Converging Worlds. Cahiers du monde russe, vol. 45, no $3 / 4$.

Burbank J. (2004) Russian Peasants Go to Court: Legal Culture in the Countryside, 1905-1917, Bloomington: Indiana University Press.

Burds J. (1998) Peasant Dreams and Market Politics: Labor Migration and the Russian Village, 1861-1905, Pittsburgh: University of Pittsburgh Press.

Bushnell J. (1985) Mutiny amid Repression: Russian Soldiers in the Revolution of 1905-06, Bloomington: Indiana University Press.

Bushnell J. (1988) Peasant economy and peasant revolution at the turn of the century: Neither immiseration nor autonomy. Russian Review, vol. 47, no 1.

Bushnell J. (2017) Russian Peasant Women Who Refused to Marry: Spasovite Old Believers in the 18th-19th Centuries, Bloomington: Indiana University Press.

Chulos C.J. (2003) Converging Worlds: Religion and Community in Peasant Russia, 1861-1917, DeKalb: Northern Illinois University Press.

Confino M. (1963) Domaines et seigneurs en Russie vers la fin du XVIIle siècle, Paris: Institut d'études slaves de l'Université de Paris.

Confino M. (1969) Systèmes agraires et progrès agricole, Paris: Mouton.

Czap Jr.P. (1983) A large family: The 'peasant's greatest wealth': Serf households in Mishino, Russia, 1814-1858. Family Forms in Historic Europe, Cambridge: Cambridge University Press, pp. 105-151.

Czap Jr.P. (1978) Marriage and the peasant joint family in the era of serfdom. D.L. Ransel (Ed.) The Family in Imperial Russia: New Lines of Historical Research, Urbana: University of Illinois Press, pp. 103-128.

Darrow D.W. (2001) From commune to household: Statistics and the social construction of Chaianov's theory of peasant economy. Comparative Studies in Society and History, vol. 43, no 4 .

Darrow D.W. (2018) Tsardom of Sufficiency, Empire of Norms: Statistics, Land Allotments, and Agrarian Reform in Russia, 1700-1921, Montreal: McGill-Queen's University Press. 
Djurfeldt G. (1988) Shanin's Russia. Acta Sociologica, vol. 31, no 2.

Edelman R. (1987) Proletarian Peasants: The Revolution of 1905 in Russia's Southwest, Ithaca: Cornell University Press.

Eklof B. (1988) Ways of seeing: Recent Anglo-American studies of the Russian peasant (18611914). Jahrbücher für Geschichte Osteuropas, vol. 36, no 1.

Eklof B. (1986) Russian Peasant Schools: Officialdom, Village Culture, and Popular Pedagogy, 1861-1914, Berkeley: University of California Press.

Engel B.A. (1994) Between the Fields and the City: Women, Work, and Family in Russia, 18611914, Cambridge: Cambridge University Press.

Engel B.A. (1983) Mothers and Daughters: Women of the Intelligentsia in Nineteenth Century Russia, Cambridge: Cambridge University Press.

Engel B.A. (1986) The woman's side: Male out-migration and the family economy in Kostroma Province. Slavic Review, vol. 45, no 2.

Engel B.A. (1990) Peasant morality and pre-marital relations in late 19th century Russia. Journal of Social History, vol. 23, no 4.

Engel B.A. (1997) Not by bread alone: Subsistence riots in Russia during World War I. Journal of Modern History, vol. 69, no 4.

Engelstein L. (1982) Moscow, 1905: Working-Class Organization and Political Conflict, Stanford: Stanford University Press.

Engelstein L. (1999) Castration and the Heavenly Kingdom: A Russian Folktale, Ithaca: Cornell University Press.

Evans Clements B. (1979) Bolshevik Feminist: The Life of Aleksandra Kollontai, Bloomington: Indiana University Press.

Farnsworth B. (1986) The litigious daughter-in-law: Family relations in rural Russia in the second half of the nineteenth-century. Slavic Review, vol. 45, no 1.

Farnsworth B. (1990) The soldatka: Folklore and court record. Slavic Review, vol. 49, no 1.

Frank S.P. (1987) Popular justice: Community and culture among the Russian peasantry, 18701900. Russian Review, vol. 46, no 3 .

Frank S.P. (1992) Simple folk, savage customs? Youth, sociability and the dynamics of culture in rural Russia, 1861-1914. Journal of Social History, vol. 25, no 4.

Frank S.P. (1994) Confronting the domestic other: Rural popular culture and its enemies in finde-siècle Russia. S.P. Frank, M.D. Steinberg (Eds.). Cultures in Flux: Lower-Class Values, Practices, and Resistance in Late Imperial Russia, Princeton: Princeton University Press.

Frank S.P. (1996) Narratives within numbers: Women, crime and justicial statistics in Imperial Russia, 1834-1913. Russian Review, vol. 55, no 4.

Frank S.P. (1999) Crime, Cultural Conflict, and Justice in Rural Russia, 1856-1914, Berkeley: University of California Press.

Frank S.P., Steinberg M.D. (1994) Introduction. S.P. Frank, M.D. Steinberg (Eds.) Cultures in Flux: Lower-Class Values, Practices, and Resistance in Late Imperial Russia, Princeton: Princeton University Press.

Frierson C. (1987) Razdel: The peasant family divided. Russian Review, vol. 46, no 1.

Frierson C.A. (1993) Peasant Icons: Representations of Rural People in Late Nineteenth-Century Russia, New York: Oxford University Press.

Frierson C.A. All Russia is Burning! A Cultural History of Fire and Arson in Late Imperial Russia, Seattle: University of Washington Press.

Friesen L.G. (1994) Bukkers, plows and lobogreikas: Peasant acquisition of agricultural implements in Russia before 1900. Russian Review, vol. 53, no 3.

Friesen L.G. (2008) Rural Revolutions: Peasants, Nobles, and Estate Owners in Southern Ukraine, 1775-1905, Cambridge: Distributed by Harvard University Press for the Harvard Ukrainian Research Institute.

Gatrell P. (1986) The Tsarist Economy, 1850-1917, London: B.T. Batsford.

Gaudian C. (1998) No place to lay my head: Marginalization and the right to land during the Stolypin reforms. Slavic Review, vol. 57, no 4.

\section{C.D. Worobec}

The influences of

A.V. Chayanov and Teodor Shanin on the English-language historiography of peasants in the Russian Empire 
Gaudin C. (2007) Ruling Peasants: Village and State in Late Imperial Russia, DeKalb: Northern Illinois University Press.

Gerasimov I.V. (2004) On the limitations of a discursive analysis of 'experts and peasants' (An attempt at the internationalization of a discussion in Kritika). Jahrbücher für Geschichte Osteuropas, vol. 52, no 2.

Gerasimov I.V. (2009) Modernism and Public Reform in Late Imperial Russia: Rural Professionals and Self-Organization, 1905-1930, Houndmills, Basingstoke: Palgrave MacmilIan.

Gleason A. (1980) Young Russia: The Genesis of Russian Radicalism in the 186os, New York: Viking Press.

Glickman R.L. (1991) The peasant woman as healer. B. Evans Clements, B.A. Engel, C.D. Worobec (Eds.). Russia's Women: Accommodation, Resistance, Transformation, Berkeley: University of California Press, pp. 148-162.

Goubert P. (1986) French Peasantry in the Seventeenth Century, trans. by I. Patterson, Cambridge: Cambridge University Press.

Gregory P.R. (1983) The Russian agrarian crisis revisited. R.C. Stuart (Ed.) The Soviet Rural Economy, Totowa: Rowman and Allanheld, pp. 21-31.

Gregory P.R. (1994) Before Command: An Economic History of Russia from Emancipation to the First Five-Year Plan, Princeton: Princeton University Press, pp. 37-54.

Henry L. (1967) Manuel de démographie historique, Paris: Centre de recherches d'histoire et de philology.

Heretz L. (2008) Russia on the Eve of Modernity: Popular Religion and Traditional Culture under the Last Tsars, Cambridge: Cambridge University Press.

Hoch S.L. (1982) Serfs in Imperial Russia: Demographic insights. Journal of Interdisciplinary History, vol.c13, no 2.

Hoch S.L. (1986) Serfdom and Social Control in Nineteenth Century Russia: Petrovskoe, a Village in Tambov, Chicago: Chicago University Press.

Johnson R.E. (1991) Review of Shanin's Russia as a 'Developing Society'. American Historical Review, vol. 96, no 4.

Johnson R.E. (1979) Peasant and Proletarian: The Working Class of Moscow in the Late Nineteenth Century, New Brunswick: Rutgers University Press.

Karagodin A. (2002) 'Velikorusskii Pakhar' at the global village: Comparing methods and approaches in Western and Russian historiographies of the post-emancipation Russian peasantry. Revolutionary Russia, vol. 15, no 2.

Kingston-Mann E. (1991) Peasant communes and economic innovation: A preliminary inquiry. Peasant Economy, Culture, and Politics of European Russia, 1800-1921, Princeton: Princeton University Press, pp. 23-51.

Kingston-Mann E. (1999) In Search of the True West: Culture, Economics, and Problem of Russian Development, Princeton: Princeton University Press.

Kingston-Mann E., Mixter T., Burds J. (Eds.) (1991) Peasant Economy, Culture, and Politics of European Russia, 1800-1921, Princeton: Princeton University Press.

Kivelson V.A., Greene R.H. (Eds.) (2003) Orthodox Russia: Belief and Practice under the Tsars, University Park: Pennsylvania State University Press.

Kizenko N. (2000) A Prodigal Saint: Father John of Kronstadt and the Russian People, University Park: Pennsylvania State University Press.

Koenker D.P. (1981) Moscow Workers and the 1917 Revolution, Princeton: Princeton University Press.

Kopsidis M., Bruisch K., Bromley D.W. (2015) Where is the backward Russian peasant? Evidence against the superiority of private farming, 1883-1913. Journal of Peasant Studies, vol. 42, no 2.

Kotsonis Y. (1999) Making Peasants Backward: Agricultural Cooperatives and the Agrarian Question in Russia, 1861-1914, New York: St. Martin's Press.

Laslett P., Wall R. (Eds.) (1972) Household and Family in Past Time: Comparative Studies in the Size and Structure of the Domestic Group over the Last Three Centuries in England, 
France, Serbia, Japan and Colonial North America, with Further Materials from Western Europe, Cambridge: Cambridge University Press.

le Roy Ladurie E. (1974) The Peasants of Languedoc, trans. by J. Day, Urbana: University of Illinois Press.

le Roy Ladurie E. (1978) Montaillou: Cathars and Catholics in a French Village, 1294-1324, trans. by B. Bray, London: Scolar;

Leonard C.S. (2011) Agrarian Reform in Russia: The Road from Serfdom, Cambridge: Cambridge University Press, pp. 137-140.

Leonard C.S., Grantham G. (Eds.) (1989) Agrarian Organization in the Century of Industrialization: Europe, Russia, and North America, Berkeley: University of California Press.

Levin E. (1993) Dvoeverie and popular religion. S.K. Batalden (Ed.) Seeking God: The Recovery of Religious Identity in Orthodox Russia, Ukraine, and Georgia, DeKalb: Northern Illinois University Press, pp. 29-52.

Lewin M. (1985) The Making of the Soviet System: Essays in the Social History of Interwar Russia, New York: Pantheon Books.

Meehan B. (1993) Holy Women of Russia: The Lives of Five Orthodox Women Offer Spiritual Guidance for Today, San Francisco: HarperSanFrancisco.

Miller B.R. (2013) Rural Unrest during the First Russian Revolution: Kursk Province, 1905-1906, Budapest: Central European University Press.

Moon D. (1992) Russian Peasant and Tsarist Legislation on the Eve of Reform: Interaction between Peasants and Officialdom, 1825-1855, Houndmills, Basingstoke, Hampshire: Macmillan.

Moon D. (1999) The Russian Peasantry 1600-1930: The World the Peasants Made, London: Longman.

Moon D. (2005) Late Imperial peasants. I.D. Thatcher (Ed.) Late Imperial Russia: Problems and Prospects, Manchester: Manchester University Press.

Moon D. (2013) The Plough that Broke the Steppes: Agriculture and Environment on Russia's Grasslands, 1700-1914, Oxford: Oxford University Press.

Moore C.M. (2018) Land for service: Russian peasant views of a postwar land settlement during World War I. Russia's Home Front in War and Revolution, 1914-22, book 3: National Disintegration, C. Read, P. Waldron, A. Lindenmeyr (Eds.), Bloomington: Slavica Publishers, pp. 297-320.

Moore C.M. (2019) Review of Darrow's Tsardom of Sufficiency. Agricultural History, vol. 93, no 3 .

Nikulin A., Trotsuk I. (2020) Teodor Shanin's scientific legacy: Genres and models for understanding social worlds. Journal of Peasant Studies, vol. 47, no 7.

Ortner S.B., Whitehead H. (Eds.) (1981) Sexual Meanings: The Cultural Construction of Gender and Sexuality, Cambridge: Cambridge University Press.

Paert I. (2010) Spiritual Elders: Charisma and Tradition in Russian Orthodoxy, DeKalb: Northern Illinois University Press.

Pallot J. (1991) Women's domestic industries in Moscow Province, 1880-1900. B. Evans Clements, B.A. Engel, C.D. Worobec (Eds.) Russia's Women: Accommodation, Resistance, Transformation,. Berkeley: University of California Press, pp. 163-184.

Pallot J. (1999) Land Reform in Russia, 1906-1917: Peasant Responses to Stolypin's Project of Rural Transformation, Oxford: Clarendon Press.

Poole R.A. (2018) Introduction: Faith, freedom, and the varieties of Russian religious experience. R.A. Poole, P.W. Werth (Eds.). Religious Freedom in Modern Russia, Pittsburgh: University of Pittsburgh Press, pp. 1-43.

Ransel D.L. (1988) Mothers of Misery: Child Abandonment in Russia, Princeton: Princeton University Press.

Ransel D.L. (2000) Village Mothers: Three Generations of Change in Russia and Tataria, Bloomington: Indiana University Press.

Redfield R. (1962) The Little Community, and Peasant Society and Culture, Chicago: University of Chicago Press. 
Rieber A.J. (1988) Russia as a 'Developing Society' by Teodor Shanin; Russia, 1905-07: Revolution as a Moment of Truth by Teodor Shanin. Slavic Review, vol. 47, no 1.

Robinson G.T. (1972) Rural Russia under the Old Regime: A History of the Landlord-Peasant World and a Prologue to the Peasant Revolution of 1917, Berkeley: University of California Press.

Rock S. (2007) Popular Religion in Russia: 'Double Belief' and the Making of an Academic Myth, London: Routledge.

Rosenberg W.G. (1993) Understanding peasant Russia: A review article. Comparative Studies in Society and History, vol. 35, no 4.

Scott J.C. (1976) The Moral Economy of the Peasant: Rebellion and Subsistence in Southeast Asia, New Haven: Yale University Press.

Scott J.W. (1986) Gender: A useful category of historical analysis. American Historical Review, vol. 91, no 5 .

Seregny S.J. (1989) Russian Teachers and Peasant Revolution: The Politics of Education in 1905, Bloomington: Indiana University Press.

Shanin T. (1972) The Awkward Class: Political Sociology of Peasantry in a Developing Society: Russia 1910-1925, Oxford: Clarendon Press.

Shanin T. (1986) Roots of Otherness, Russia's Turn of Century. vol. 1: Russia as a 'Developing Society', New Haven: Yale University Press.

Shanin T. (1986) Roots of Otherness, vol. 2: Russia, 1905-07: Revolution as a Moment of Truth, New Haven: Yale University Press.

Shevzov V. (2004) Russian Orthodoxy on the Eve of Revolution, Oxford: Oxford University Press.

Stanziani A. (2017) European statistics, Russian numbers, and social dynamics, 1861-1914. Slavic Review, vol. 76, no 1.

Sunderland W. (2014) Review of Moon's The Plough That Broke the Steppes. Slavic Review, vol. 73 , no 4 .

Thorner D., Kerblay B.H., Smith R.E.F. (Eds.) (1966) A.V. Chayanov on the Theory of Peasant Economy, Homewood: Richard D. Irwin.

Venturi F. (1960) Roots of revolution: A history of the populist and socialist movements in nineteenth century Russia, trans. by F. Haskell, New York: Knopf.

Wheatcroft S.G. (1991) Crises and the condition of the peasantry in late Imperial Russia. Peasant Economy, Culture, and Politics of European Russia, 1800-1921, Princeton: Princeton University Press, pp. 128-72.

Wolf E. (1966) Peasants, Englewood Cliffs: Prentice-Hall.

Worobec C.D. (1994) Death ritual among Russian and Ukrainian peasants: Linkages between the living and the dead. Cultures in Flux: Lower-Class Values, Practices, and Resistance in Late Imperial Russia, S.P. Frank, M.D. Steinberg (Eds.), Princeton: Princeton University Press, pp. 12-16.

Worobec C.D. (1986) Patterns of property devolution among Ukrainian peasants in Kiev and Kharkov Provinces. Occasional Papers of the Kennan Institute for Advanced Russian Studies, no 206.

Worobec C.D. (1991) Peasant Russia: Family and Community in the Post-Emancipation Period, Princeton: Princeton University Press.

Worobec C.D. (1992) Possessed: Women, Witches, and Demons in Imperial Russia, DeKalb: Northern Illinois University Press.

Worobec C.D. (1995) Witchcraft beliefs and practices in prerevolutionary Russian and Ukrainian villages. Russian Review, vol. 54, no 2.

Worobec C.D. (2003) Conceptual observations on the Russian and Ukrainian peasantries. Culture, Nation, and Identity: The Ukrainian-Russian Encounter, 1600-1945. A. Kappeler, Z.E. Kohut, F.E. Sysyn, M. von Hagen (Eds.), Edmonton: Canadian Institute of Ukrainian Studies Press, pp. 256-276.

Zack J. (1981) Serf and State Peasant Agriculture: Kharkov Province, 1842-1861, New York: Arno Press.

Zelnik R.E. (1971) Labor and Society in Tsarist Russia, Stanford: Stanford University Press. 
Zhbankov D.N. (1891) Babiya storona: Statistiko-etnografichesy ocherk, Kostroma: V Gub. tip. Zhuk S.I. (2004) Russia's Lost Reformation: Peasants, Millennialism, and Radical Sect in Southern Russia and Ukraine, 1830-1917, Baltimore: Johns Hopkins University Press.

\section{Влияние идей А.В. Чаянова и Теодора Шанина на англоязычную историографию крестьянства в Российской империи}

Кристин Д. Воробец, почетный профессор-исследователь, Университет Северного Иллинойса. 1425 W. Lincoln Hwy. DeKalb, IL 60115-2828. E-mail: worobec@niu.edu.

В 1980-е годы сочетание множества факторов обусловило возрождение интереса к жизни крестьянства в Российской империи, и не последнюю роль здесь сыграли работы А.В. Чаянова и Теодора Шанина. Междисциплинарное социально-историческое движение, которое избегало традиционного политикоисторического подхода с его фокусом на роли элит, оформилось еще в 196о-е годы. Весьма неожиданно прежний интерес к биографиям российских революционеров и истории зарождающегося рабочего класса и рабочего движения в целях объяснения революций 1905 и 1917 годов был дополнен, а в конце концов и вытеснен жаждой изучения крестьянства. В статье представлены выводы первой волны исследований крестьянства Российской империи и показано, почему идеи Чаянова и Шанина сохранили свое определяющее значение, несмотря на их противоречие архивным данным, микро- и региональной истории, исследованиям конфликтов внутри крестьянских домохозяйств, гендерных вопросов, ремесел и несельскохозяйственных промыслов, роста грамотности, а также исходящей и возвратной крестьянской миграции. К середине 1990-х годов стало невозможно рассуждать об обобщенном автаркичном, замкнутом, сплоченном и эгалитарном российском крестьянском обществе с его традиционными нормами и обычаями, которое спонтанно восставало против своего обнищания. Постструктуралистский поворот усилил недоверие к статистическим данным конца XIX - начала XX веков и поставил под сомнение изображения крестьян как темных, примитивных и отсталых. Хотя этот поворот практически свел на нет интерес к изучению российского крестьянства, в первом десятилетии XXI века стали вновь появляться посвященные ему исторические работы. В результате сегодня мы лучше понимаем экономическую и социальную дифференциацию крестьянства, форматы нормального политического взаимодействия крестьян с государством (далеко не всегда это было сопротивление), а также использование крестьянами юридической системы, чтобы отстаивать свои интересы в спорах с соседями и членами своей семьи. Мы также лучше понимаем функционирование моральной экономики во взаимодействии государства с его налогоплательщиками-крестьянами, и как земская статистика помогла Чаянову разработать свою блестящую модель доминирующего среднего крестьянского домохозяйства. В целом то активное начало, которым Чаянов и Шанин наделили крестьянство, заняло центральное место в историческом анализе.

Ключевые слова: Чаянов, Шанин, крестьянство, Российская империя, российское крестьянское общество, крестьянское домохозяйство, крестьянская община, традиционная политическая история, постструктуралистский поворот, моральная экономика
31

C.D. Worobec

The influences of

A.V. Chayanov

and Teodor

Shanin on the

English-language historiography of peasants in the Russian Empire 